Iğdır Üniversitesi Fen Bilimleri Enstitüsü Dergisi, 11(3): 1671-1685, 2021

Journal of the Institute of Science and Technology, 11(3): 1671-1685, 2021

Bahçe Bitkileri / Horticulture

ISSN: 2146-0574, eISSN: 2536-4618

DOI: 10.900957/jist.900957

Derleme Makalesi / Review Article

Geliș tarihi / Received: 22-03-2021

Kabul tarihi / Accepted: 14-05-2021

Atıf İçin: Öztürk A, Serttaş S, 2021. Karadeniz Bölgesinin Yumuşak Çekirdekli Meyve Üretiminde Mevcut Durumu ve Potansiyeli. Iğdır Üniversitesi Fen Bilimleri Enstitüsü Dergisi, 11(3): 1671-1685.

To Cite: Öztürk A, Serttaş S, 2021. The Current Situation and Potential of Pome Fruit Production of Black Sea Region. Journal of the Institute of Science and Technology, 11(3): 1671-1685, 2021

\title{
Karadeniz Bölgesinin Yumuşak Çekirdekli Meyve Üretiminde Mevcut Durumu ve Potansiyeli
}

\section{Ahmet ÖZTÜRK ${ }^{1 *}$, Sevgi SERTTAȘ ${ }^{1}$}

ÖZET: Çok farklı ekolojik koşullara ve coğrafik yapıya sahip olan ve bu nedenle birçok meyve türünün yetiştiriciliğinin yapılabildiği Karadeniz Bölgesi, ülkemiz meyveciliğinde oldukça önemli bir yere sahiptir. Karadeniz Bölgesi, 2573222 ton ile Türkiye meyve üretiminin \% 11.1'ini, 225 bin tonluk yumuşak çekirdekli meyve üretimi ile de ülkemiz yumuşak çekirdekli meyve üretiminin yaklaşık \% 4.4'nü gerçekleştirmektedir. Bölgede yumuşak çekirdekli meyve yetiştiriciliği yaygın olarak ev bahçeleri, meyve bahçeleri ve kapama bahçelerde yapılmaktadır. Bölge meyveciliğinde yumuşak çekirdekli meyveler \% 8.8'lik üretim payı ile sert kabuklu meyvelerden (\% 23.9) sonra ikinci sırada yer almaktadır. Bölgede yumuşak çekirdekli meyveler içerisinde en fazla elma (149 275 ton, \% 66.3) ve armut (59.931 ton, \% 26.6) üretilmektedir. Bölgede hem üretim alanı hem de üretim miktarı bakımından diğer grupta yer alan elmalar üretilirken (sırasıyla \% 37.9 ve \% 36.3) bu grubu üretim alanı bakımından Amasya (\% 20.9) üretim miktarı bakımından ise Starking (\%19.7) takip etmektedir. Karadeniz Bölgesi 1912 tonluk üretimiyle ülkemiz muşmula üretiminin \% 38.5'lik kısmını karşılamaktadır. Karadeniz Bölgesi'ndeki yumuşak çekirdekli meyve üretim potansiyeli iller bazında değerlendirildiğinde Amasya (46 004 ton), Samsun (27 874 ton), Kastamonu (21 509 ton) ve Tokat (20 450 ton) en fazla üretimi yapan illerdir. Bu çalışmada yumuşak çekirdekli meyveler içerisinde en fazla üretilen türlerin Karadeniz Bölgesi ve Türkiye üretimindeki mevcut durumu ve potansiyeli detaylı olarak ele alınmıştır.

Anahtar Kelimeler: Armut, Ayva, Elma, Karadeniz Bölgesi, Yumuşak Çekirdekliler

\section{The Current Situation and Potential of Pome Fruit Production of Black Sea Region}

ABSTRACT: The Black Sea Region, having very different ecological conditions and geographical structures and therefore can grow many fruit species, has a very important place in fruit growing in our country. The Black Sea Region realizes $11.1 \%$ of Turkey's fruit production with 2573222 tons, and approximately $4.4 \%$ of our country's pome fruit production about 225 thousand tons of pome fruit production. Pome fruit growing in the region is mainly performed in home gardens, fruit gardens and commercial orchards. Pome fruits with 8.8 $\%$ portion have second place after nuts $(23.9 \%)$ in fruit growing of the region. Apple (149 275 tons, $66.3 \%$ ) and pear (59 931 tons, $26.6 \%$ ) are produced as the highest amount among pome fruits in the region. In the region, while apples are produced in terms of both production amount and area with the other apple group (36.3 $\%$ and $37.9 \%$, respectively), the Amasya apple (20.9\%) in terms of production area and the Starking apple $(19.7 \%)$ in terms of production amount are followed in this group. The Black Sea Region with 1912 tons of production supplies $38.5 \%$ of total medlar production of Turkey. When the potential of pome fruit production in the Black Sea Region is evaluated, Amasya (46 004 tons), Samsun (27 874 tons), Kastamonu (21 509 tons) and Tokat (20 450 tons) are the main producer cities. In this study, the current situation and potential of the most produced pome fruit species in the fruit production of the Black Sea Region and Turkey are discussed in detail.

Keywords: Pear, Quince, Apple, Black Sea Region, Pome Fruits

${ }^{1}$ Ahmet ÖZTÜRK (Orcid ID: 0000-0002-8800-1248), Sevgi SERTTAŞ (Orcid ID: 0000-0002-5557-308X), Ondokuz Mayıs Üniversitesi, Ziraat Fakültesi, Bahçe Bitkileri Bölümü, Samsun, Türkiye

*Sorumlu Yazar/Corresponding Author: Ahmet ÖZTÜRK, e-mail: ozturka@omu.edu.tr 


\section{GİRIS}

Çok farklı iklim koşullarına sahip olan Türkiye, pek çok meyve türünün anavatanı veya anavatanları arasında yer almaktadır (Davis, 1972). Dünya'da kültürü yapılan 138 meyve türünden 16's1 subtropik meyve türü olmak üzere 75 'den fazla meyve türü Türkiye'de yetişebilmektedir (Ağaoğlu ve ark., 2015). Dünya'da FAO verilerine göre 2019 yılında yaklaşık 883 milyon ton olan meyve üretiminde Türkiye yaklaşı 22 milyon tonluk üretime sahiptir. Türkiye bu üretimiyle dünya meyve üretiminin yaklaşı \% 2.6'sını karşılayan ve meyve üretiminde ilk 10 ülke içerisinde yer almaktadır. Türkiye bu üretimi ile yaklaşık 81 milyon tonluk meyve üretimine sahip olan Avrupa'da \% 29.0'luk üretim payına sahiptir (FAOSTAT, 2021). Ülkemizde ekstrem iklim koşullarının görüldüğü bazı iller dışında hemen hemen her bölgede ekonomik anlamda meyve yetiştiriciliği yapılabilmektedir. Yaklaşık 231.3 milyon dekar olan ülkemiz tarım alanlarının 35.6 milyon dekarlık kısmında (\% 15.4) yaklaşık 23.3 milyon tonluk meyve üretimi yapılmaktadır. Bu meyve üretim alanı içerisinde \%37.9'luk payla sert kabuklu meyveler en yüksek payı alırken bunu sert çekirdekliler, üzüm-üzümsü, yumuşak çekirdekli meyveler, turunçgiller ve diğer meyveler takip etmektedir. Üretim miktarı bakımından ise en yüksek payı \% 23.4'lük pay ile üzüm ve üzümsü meyveler alırken bunu yumuşak çekirdekliler (\%22.0), turunçgiller (\%18.7), sert çekirdekliler (\% 18.6), diğer (\% 10.9) ve sert kabuklu meyveler (\%6.4) takip etmektedir. 27.2 milyon dekar tarım arazisine sahip olan Karadeniz Bölgesi, 7.7 milyon dekar meyvecilik alanı ile Türkiye meyve üretim alanlarının \% 22.3'ünü kapsamaktadır. Bölgede meyvecilik bakımından önde gelen iller Rize, Trabzon, Ordu, Artvin, Samsun, Tokat ve Amasya'dır (TÜİK, 2021).

Ülkemizde en fazla yağış alan Karadeniz Bölgesi’nin topoğrafyası makineli tarımı sınırlandırmaktadır. Bu durum özellikle Doğu Karadeniz Bölümü’nde belirgindir. Özellikle Rize ve çevresinin bol yağışlı olması, çay tarımı için elverişli ortam oluştururken, dünyanın en kaliteli findıkları Ordu, Giresun ve Trabzon illerinde üretilmektedir. Ülkemiz meyveciliğinde önemli yer tutan fındığın da üretim miktarı bakımından büyük bir kısmı (\% 83.3) bölgede üretilirken bu ürünleri üretim miktarı bakımından kızılcık (\% 76.2), muşmula (\% 38.5), kivi (\% 32.9), maviyemiş (\% 25.7), hünnap (\% 24.7) kestane (\% 21.2) izlemektedir. Bölgede sahil kesiminde özellikle düz veya düze yakın alanlarda ve iç kesimlerde iklimin karasala dönüştüğü kesimlerde tarla tarımı, eğimin arttığı ve iklimin daha ılıman olduğu kesimlerde meyve yetiştiriciliği yapılmaktadır (Öztürk ve Serttaş, 2018; Anonim, 2021). Ülkemiz meyve üretiminde yaklaşık 5.2 milyon tonluk üretimiyle 2. sırada yer alan yumuşak çekirdekli meyveler Karadeniz bölgesinde yaklaşı 225 bin ton üretilmektedir. Bölgede yaklaşık 150 bin ton elma, 60 bin ton armut, 10 bin ton ayva, 3.6 bin ton trabzonhurması, 1.9 bin ton muşmula ve 184 ton yenidünya üretilmektedir. Ayrıca Karadeniz Bölgesi sahip olduğu engebeli arazi yapısı, kimyasal girdi (gübre, ilaç vb.) kullanımının düşük olması, zengin flora ve faunasının bulunması, sanayi tesislerine dayalı kirliliğin az olmasından dolayı organik tarım potansiyeli yüksek bir bölgedir (Öztürk ve Karabulut, 2017).

Karadeniz Bölgesi, meyvecilik için uygun iklim ve toprak koşullarına sahip olması, üretim alanlarının fazla olması, bölgedeki ürünlerin değerlendirilmesi acısından tarım sanayisinin (özellikle meyve suyu) gelişmiş olması ve verimli ovalara sahip olması dolayısıyla meyve yetiştiriciliği açısından ekonomik olarak önemli bir potansiyele sahiptir (Öztürk ve Serttaş, 2018). Bölgede elma, armut, ayva, muşmula, trabzonhurması, yeni dünya, alıç, ahlat ve üvez gibi yumuşak çekirdekli meyve türleri yetişmektedir. Karadeniz Bölgesi'nde Samsun, Amasya, Tokat gibi illerde özellikle elma, armut ve ayva gibi yumuşak çekirdekli meyve türlerinde kapama bahçeler şeklinde yetiştiricilik söz konusudur. Bölgede genellikle yumuşak çekirdekli meyve türleri kapama bahçeler şeklinde değil, 
genel olarak Doğu Karadeniz Bölümü'nde fındık ve çay bahçelerinin arasında tek tek ağaçlar şeklinde, Orta ve Batı Karadeniz Bölümü'nde ise orman ve tarla kenarlarında sınır ağacı olarak veya ev bahçelerinde dağınık olarak bulunmaktadır (Çiftçi ve ark., 2011; Dumanoğlu ve ark., 2011; Öztürk ve Demirsoy, 2013; Yılmaz ve Gerçekçioğlu, 2013; Çakır ve Öztürk, 2019; Maral-Gürbüz ve Bostan, 2020). Buna ilaveten son yıllarda modern tarım tekniklerinin de kullanıldığı özellikle elma, armut ve ayvada kapama bahçeler de kurulmaya başlanmıştır. Bölgede standart çeşitlerin yanı sıra geçmişten günümüze kadar önemini koruyan yumuşak çekirdekli yerel meyve türleri ve çeşitleri de mevcuttur. Bölgede yapılan pek çok çalışmada bölgenin yumuşak çekirdekli meyve türlerine ait yerel çeşit potansiyeli ortaya konulmuş, bunların farklı ıslah çalışmalarında kullanılmak amacıyla koruma altına alınması vurgulanmıştır (Karadeniz ve Şen, 1990; Karadeniz ve Kalkışım, 1996; Özkan ve ark., 1997; Bostan ve İslam 2007; Demirsoy ve ark., 2007; Serdar ve ark., 2007; Aygün ve Ülgen, 2009; Bostan, 2009; Yarılgaç ve ark., 2009; Çiftçi ve ark., 2011; Saraçoğlu ve ark., 2011; Bostan ve Acar, 2012; Aygün ve Taşc1, 2013; Öztürk ve Demirsoy, 2013; Tepe, 2013; Y1lmaz ve Gerçekçioğlu, 2013; Bak ve ark., 2016; Bostan ve Çelikel-Çubukçu, 2016; Karakaya ve ark., 2016; Şenyurt ve ark., 2016; Cevahir ve Bostan, 2017; Yarılgaç ve ark., 2017; Dost ve Dumanoğlu, 2018; Öztürk ve Öztürk, 2018; Çakır ve Öztürk, 2019; Maral-Gürbüz ve Bostan, 2020). Ancak bu yerel çeşitler çoğunlukla kendi mahallinde yerel pazarlarda satılmaktadır.

$\mathrm{Bu}$ makalede TÜIKK tarafından istatistiksel verileri yayınlanan ve yumuşak çekirdekli meyve türleri içerisinde üretim alanı ve miktarı bakımından en fazla paya sahip olan elma, armut, ayva, yenidünya, trabzonhurması ve muşmulanın ülkemiz ve Karadeniz Bölgesi’ndeki üretim alanı ve miktarlarındaki değişimler incelenmiş olup bu türlerin bölgedeki mevcut durumu ve potansiyeli ile gelecekteki durumları ortaya konulmaya çalışılmıştır.

\section{Karadeniz Bölgesinin Coğrafik Konumu ve İklim Özellikleri}

Türkiye'nin kuzeyinde yer alan Karadeniz Bölgesi ismini aldığı kuzeyindeki Karadeniz boyunca doğuda Gürcistan sınırından başlayarak, batıda Sakarya Ovası ile Bilecik'in doğusuna kadar uzanır. Türkiye yüzölçümünün \% 18'ine sahip olan bölge, yüzölçümü bakımından ülkemizin üçüncü büyük bölgesidir. Karadeniz Bölgesi, batı, orta ve doğu olmak üzere 3 bölümden oluşmaktadır. Bölgede Artvin, Rize, Trabzon, Gümüşhane, Bayburt, Giresun, Ordu, Tokat, Samsun, Amasya, Sinop, Çorum, Kastamonu, Bartın, Karabük, Zonguldak, Düzce, Bolu olmak üzere toplam 18 il bulunmaktadır. Karadeniz Bölgesi bol yağış almakta ve kıyı bölgelerde yazlar serin $\left(23-24{ }^{\circ} \mathrm{C}\right)$, kışlar 1 lık $\left(5-7{ }^{\circ} \mathrm{C}\right)$ Karadeniz iklimi, iç kesimlerde ise daha çok karasal iklim görülmektedir. Dağların kıyıya paralel uzanması tarım alanlarını kısıtlamakta olup ikliminde farklı olmasına sebep olmaktadır. Ülkemizin en fazla yağış alan bölgesi olan Karadeniz bölgesinde dağların kıyı kesimin nemli olan havasının iç kesimlere geçmesini engellemesi bitki örtüsünün de farklılık göstermesine neden olmaktadır. Kıyıda yaz mevsiminin yağışlı ve bulutlu olması buğday, pamuk gibi ürünlerin yetiştirilmesine engel olurken bulutluluğun çok olması sebze, üzüm, şekerpancarı gibi ürünlerin yetiştirilmesini sınırlandırır (Anonim, 2021).

\section{Yumuşak Çekirdekli Meyve Üretiminin Türkiye ve Karadeniz Bölgesindeki Durumu}

Türkiye'de 2005-2020 yılları arasındaki meyve üretim miktarları ve bu üretim içerisindeki yumuşak çekirdekli meyve türlerinin (armut, ayva, elma, muşmula, trabzonhurması ve yenidünya) üretim alanı ve üretim miktarı ve payları Çizelge 1'de verilmiştir. Türkiye'de 2005 yılında 27.7 milyon dekar olan meyve üretim alanı içerisinde yumuşak çekirdekli meyvelerin üretim alanı yaklaşık 1.9 milyon dekar iken, 2020 yılında ülkemiz meyve üretim alanı yaklaşık 34.9 milyon dekara, yumuşak çekirdekli meyvelerin üretim alanı ise yaklaşık 2.1 milyon dekara yükselmiştir. Türkiye'de 2005 yılı 
meyve üretim miktarı yaklaşık 15.9 milyon ton iken üretimin \% 19.5 'i (3.1 milyon ton) yumuşak çekirdekli meyve türlerine aittir. 2020 yılında ise Türkiye toplam meyve üretimi 23.3 milyon tona, yumuşak çekirdekli meyve üretimi ise 5.1 milyon tona yükselmiştir. Buna göre, 2005-2020 yılları arasında hem ülkemiz toplam meyve üretim alanı ve miktarında hem de yumuşak çekirdekli meyve türlerinin üretim alanı ve miktarında artış görülmüştür. Genel olarak Türkiye'de yumuşak çekirdekli meyvelerin meyve üretim alanındaki payı 2005 yılında \% 6.9 iken, 2020 yılında \% 6.0'a düşmüş, üretim miktarındaki payı ise \% 19.3'den azalan ve artan bir seyir izleyerek \% 22.0'ye yükselmiştir (Çizelge 1). Toplam meyve üretimi içerisinde yumuşak çekirdekli meyve türlerinin üretim alanında azalış görülürken üretim miktarında yıllar itibarıyla görülen artış verimli çeşitlerle tesis edilen bahçelerde kültürel uygulamaların ideal bir şeklide yerine getirilmesinin sonucu olarak değerlendirilebilir. Karadeniz Bölgesi’nin sahip olduğu iklim özellikleri “Granny Smith”, "Fuji” ve "Royal Gala" gibi güneş yanıklığına hassas olan elma çeşitlerinin yetiştiriciliğine uygun olduğu (Dumanoğlu ve ark., 2009) ve bölgenin ekolojisine uygun mantari hastalıklara dayanıklı çok sayıda yerel elma çeşidinin bulunduğu bildirilmiştir (Dumanoğlu ve ark., 2011; Dost ve Dumanoğlu, 2018). Yine bölgenin ayva, muşmula, trabzonhurması ve özellikle de elma ve armut bakımından önemli bir potansiyelinin olduğu yapılan çalışmalarda vurgulanmıştır (Karadeniz ve Şen, 1990; Karadeniz ve Kalkışım, 1996; Özkan ve ark., 1997; Bostan ve İslam 2007; Demirsoy ve ark., 2007; Serdar ve ark., 2007; Aygün ve Ülgen, 2009; Bostan, 2009; Yarılgaç ve ark., 2009; Dumanoğlu ve ark., 2011; Bostan ve Acar, 2012; Aygün ve Taşc1, 2013; Öztürk ve Demirsoy, 2013; Yılmaz ve Gerçekçioğlu, 2013; Bostan ve Çelikel-Çubukçu, 2016; Karakaya ve ark., 2016; Cevahir ve Bostan, 2017; Dost ve Dumanoğlu, 2018).

Çizelge 1. Türkiye 2005-2020 yılları toplam meyve ve yumuşak çekirdekli meyve üretim alan ve miktarları

\begin{tabular}{|c|c|c|c|c|c|c|}
\hline \multirow[b]{2}{*}{ Yillar } & \multicolumn{2}{|c|}{ Türkiye Toplam Meyve } & \multicolumn{2}{|c|}{ Yumuşak Çekirdekli Meyve } & \multirow{2}{*}{$\begin{array}{l}\text { Yumuşak Çekirdekli } \\
\text { Meyvelerin Türkiye } \\
\text { Meyve Üretim } \\
\text { Alanındaki Payı (\%) }\end{array}$} & \multirow{2}{*}{$\begin{array}{l}\text { Yumuşak Çekirdekli } \\
\text { Meyvelerin Türkiye } \\
\text { Meyve Üretim } \\
\text { miktarındaki Payı (\%) }\end{array}$} \\
\hline & $\begin{array}{r}\text { Üretim } \\
\text { Alanı (da) }\end{array}$ & $\begin{array}{r}\text { Üretim } \\
\text { Miktarı (ton) }\end{array}$ & $\begin{array}{r}\text { Üretim } \\
\text { Alanı (da) }\end{array}$ & $\begin{array}{r}\text { Üretim } \\
\text { Miktarı (ton) }\end{array}$ & & \\
\hline 2005 & 27764560 & 15907479 & 1904770 & 3065100 & 6.9 & 19.3 \\
\hline 2006 & 28488617 & 16111876 & 1925253 & 2462075 & 6.8 & 15.3 \\
\hline 2007 & 28648793 & 15465865 & 1868540 & 2949486 & 6.5 & 19.1 \\
\hline 2008 & 29035613 & 16694268 & 1869320 & 2996596 & 6.4 & 17.9 \\
\hline 2009 & 28944228 & 17492066 & 1906663 & 3305363 & 6.6 & 18.9 \\
\hline 2010 & 29558705 & 17691311 & 1934442 & 3143839 & 6.5 & 17.8 \\
\hline 2011 & 30330433 & 18224617 & 1961548 & 3238935 & 6.5 & 17.8 \\
\hline 2012 & 31344779 & 19112484 & 2069471 & 3517311 & 6.6 & 18.4 \\
\hline 2013 & 31686656 & 19175395 & 2057916 & 3780372 & 6.5 & 19.7 \\
\hline 2014 & 31829527 & 18180512 & 2043799 & 3100527 & 6.4 & 17.1 \\
\hline 2015 & 32176973 & 18852946 & 2053989 & 3196929 & 6.4 & 17.0 \\
\hline 2016 & 32588204 & 20043529 & 2086053 & 3577330 & 6.4 & 17.8 \\
\hline 2017 & 32808797 & 21880293 & 2112367 & 3766785 & 6.4 & 17.2 \\
\hline 2018 & 33756065 & 21974562 & 2120984 & 4389245 & 6.3 & 20.0 \\
\hline 2019 & 34271460 & 21985901 & 2119334 & 4402294 & 6.2 & 20.0 \\
\hline 2020 & 34899712 & 23270769 & 2097615 & 5117333 & 6.0 & 22.0 \\
\hline
\end{tabular}

Türkiye ve Karadeniz Bölgesi'ndeki yumuşak çekirdekli meyve türlerinin 2005-2020 yılları arasındaki üretim alanı ve miktarları ve payları Çizelge 2'de verilmiştir. Karadeniz Bölgesi'nde 2005 yılında 121440 da alandan 220614 ton, 2020 yılında ise 87497 bin da alandan 225194 ton yumuşak çekirdekli meyve üretimi gerçekleştirilmiştir. Buna göre, 2005-2020 y1lları arasında ülkemizde 2018 yılına kadar yumuşak çekirdekli meyve üretim alan ve miktarında artış meydana gelirken 2019 ve 
2020 yıllarında azalma meydana gelmiştir. Karadeniz Bölgesi'nde 2005-2020 yılları arasında üretim alanında azalma görülürken üretim miktarında ise artış olmuştur. Türkiye yumuşak çekirdekli meyve üretim alanı ve miktarı içerisinde Karadeniz Bölgesi yumuşak çekirdekli meyve üretim alan ve miktarının yıllar itibarıyla azaldığı görülmektedir. Belirtilen yıllar arasında bölgedeki yumuşak çekirdekli meyve üretim alanın payı \% 6.4'den \% 4.2'ye, üretim miktarının payı ise \% 7.2'den \% 4.4'e düşmüştür. 2019 yılına kadar ülkemiz meyve üretim alan ve miktarında görülen artış Karadeniz Bölgesi'nde de görülürken 2020 yılında Türkiye yumuşak çekirdekli meyve üretim miktarı artarken Karadeniz Bölgesi'nde hem üretim alanı hem de üretim miktarı önceki yıllara göre azalmıştır (Çizelge 2). Bölgedeki bu azalışta yumuşak çekirdekli meyve türlerinin ekonomik getirisinin bölgede üretilen çay, findık, kiraz ve kivi gibi ürünlere göre düşük olmasından kaynaklandığı düşünülmektedir.

Çizelge 2. Türkiye ve Karadeniz Bölgesi'nin 2005-2020 yılları yumuşak çekirdekli meyve türlerinin üretim alan ve miktarları ve bölgedeki payları (\%)

\begin{tabular}{|c|c|c|c|c|c|c|}
\hline \multirow[b]{3}{*}{ Yillar } & \multicolumn{4}{|c|}{ Yumuşak Çekirdekli Meyveler } & \multirow{3}{*}{$\begin{array}{c}\text { Karadeniz Bölgesindeki } \\
\text { Yumuşak Çekirdekli } \\
\text { Meyvelerin Türkiye } \\
\text { Üretim Alanındaki } \\
\text { Payı (\%) }\end{array}$} & \multirow{3}{*}{$\begin{array}{c}\text { Karadeniz } \\
\text { Bölgesindeki Yumuşak } \\
\text { Çekirdekli Meyvelerin } \\
\text { Türkiye Üretim } \\
\text { Miktarındaki Payı }(\%)\end{array}$} \\
\hline & \multicolumn{2}{|c|}{ Türkiye } & \multicolumn{2}{|c|}{ Karadeniz Bölgesi } & & \\
\hline & $\begin{array}{c}\text { Üretim } \\
\text { Alanı (da) }\end{array}$ & $\begin{array}{c}\text { Üretim } \\
\text { Miktarı (ton) }\end{array}$ & $\begin{array}{c}\text { Üretim } \\
\text { Alanı (da) }\end{array}$ & $\begin{array}{c}\text { Üretim } \\
\text { Miktar1 (ton) }\end{array}$ & & \\
\hline 2005 & 1904770 & 3065100 & 121440 & 220614 & 6.4 & 7.2 \\
\hline 2006 & 1925253 & 2462075 & 127213 & 152823 & 6.6 & 6.2 \\
\hline 2007 & 1868540 & 2949486 & 117045 & 201179 & 6.3 & 6.8 \\
\hline 2008 & 1869320 & 2996596 & 117150 & 209414 & 6.3 & 7.0 \\
\hline 2009 & 1906663 & 3305363 & 113436 & 212175 & 5.9 & 6.4 \\
\hline 2010 & 1934442 & 3143839 & 120142 & 237638 & 6.2 & 7.6 \\
\hline 2011 & 1961548 & 3238935 & 116458 & 238368 & 5.9 & 7.4 \\
\hline 2012 & 2069471 & 3517311 & 115510 & 254205 & 5.6 & 7.2 \\
\hline 2013 & 2057916 & 3780372 & 111288 & 240621 & 5.4 & 6.4 \\
\hline 2014 & 2043799 & 3100527 & 105006 & 183468 & 5.1 & 5.9 \\
\hline 2015 & 2053989 & 3196929 & 100590 & 233495 & 4.9 & 7.3 \\
\hline 2016 & 2086053 & 3577330 & 105102 & 213432 & 5.0 & 6.0 \\
\hline 2017 & 2112367 & 3766785 & 105346 & 241145 & 5.0 & 6.4 \\
\hline 2018 & 2120984 & 4389245 & 102471 & 233684 & 4.8 & 5.3 \\
\hline 2019 & 2119334 & 4402294 & 101614 & 243630 & 4.8 & 5.5 \\
\hline 2020 & 2097615 & 5117333 & 87497 & 225194 & 4.2 & 4.4 \\
\hline
\end{tabular}

Türkiye ve Karadeniz Bölgesi'ndeki yumuşak çekirdekli meyve türlerine ait 2005-2020 yıllarındaki meyve veren, meyve vermeyen ve toplam ağaç sayıları Çizelge 3'de verilmiştir. Ülkemizde 2005 yılında meyve veren yaştaki yumuşak çekirdekli meyve türlerine ait ağaç sayısı 52 814000 adet iken 2020 yılında bu sayı 83530496 âdete yükselmiştir. Yine ülkemizdeki yumuşak çekirdekli meyve türlerine ait 2005 yılındaki meyve vermeyen yaştaki ağaç sayısı 52523536 adet; toplam ağaç sayısı 105337536 adet iken 2020 yılında meyve vermeyen yaştaki ağaç sayısı 19119 971 âdete toplam ağaç sayısı 102650671 âdete düşmüştür. Karadeniz Bölgesi'nde 2005 yılında yumuşak çekirdekli meyve türlerine ait ağaç sayısı meyve veren yaşta 7857991 adet, meyve vermeyen yaşta 1585359 adet ve toplam 9443350 adet iken 2020 yılında meyve veren yaşta 7010 852 adet, meyve vermeyen yaşta 1722202 adet ve toplam 8636637 adettir. Bölgede 2005 yılına göre 2020 yılında meyve veren ve meyve vermeyen yaştaki ağaç sayısı ile toplam ağaç sayısında azalma görülmüştür. Yine Türkiye yumuşak çekirdekli meyve türlerine ait ağaç sayısı içerisinde Karadeniz Bölgesi'nin 2005 yılında \% 9.0 olan payı 2010 yılında \% 13.0'e yükselmiş ve bu yıldan sonra genellikle azalarak \% 8.4'e düşmüştür (Çizelge 3). Bu azalma özellikle 2017 yılından sonra daha fazla olmuştur. Bu azalmada üreticilerin yumuşak çekirdekli meyve türleri ile yeni bahçe kurulumundan vazgeçip mevcut bahçelerin yerine diğer ürün gruplarına yönelmesinin etkili olduğu düşünülmektedir. 
Yumuşak çekirdekli meyve türlerinin Türkiye ve Karadeniz Bölgesi'ndeki 2020 yılı üretim alanı ve miktarı Çizelge 4'de verilmiştir. Ülkemizde yumuşak çekirdekli meyve türleri içerisinde üretim alanı ve miktarı bakımından ilk sırayı elma almakta ve bunu sırasıyla armut, ayva, trabzonhurması, yenidünya ve muşmula izlemektedir. Karadeniz Bölgesinde ise yumuşak çekirdekli meyve türleri içerisinde üretim alanı ve miktarı bakımından ilk sırayı elma almakta ve bunu sırasıyla armut, ayva, trabzonhurması, muşmula ve yenidünya izlemektedir. Ülkemiz toplam yumuşak çekirdekli meyve üretim alanının \% 4.2'sine sahip olan Karadeniz Bölgesi üretim miktarının ise \% 4.4'üne sahiptir (Çizelge 4).

Çizelge 3. Türkiye ve Karadeniz Bölgesi yumuşak çekirdekli meyve türlerine ait 2005-2020 yıllarındaki ağaç sayıları

\begin{tabular}{|c|c|c|c|c|c|c|c|}
\hline \multirow[b]{2}{*}{ Yillar } & \multicolumn{3}{|c|}{ Türkiye } & \multicolumn{3}{|c|}{ Karadeniz Bölgesi } & \multirow{2}{*}{$\begin{array}{c}\text { Karadeniz Bölgesi’nin } \\
\text { Türkiye Toplam } \\
\text { Yumuşak Çekirdekli } \\
\text { Meyve Türlerine Ait } \\
\text { Ağaç Sayısındaki Payı } \\
(\%)\end{array}$} \\
\hline & $\begin{array}{c}\text { Meyve } \\
\text { Veren Yaşta } \\
\text { Ağaç Sayısı } \\
\text { (adet) }\end{array}$ & $\begin{array}{c}\text { Meyve } \\
\text { Vermeyen } \\
\text { Yaşta Ağaç } \\
\text { Sayısı (adet) }\end{array}$ & $\begin{array}{c}\text { Toplam } \\
\text { Ağaç Sayısı } \\
\text { (adet) }\end{array}$ & $\begin{array}{c}\text { Meyve Veren } \\
\text { Yaşta Ağaç } \\
\text { Sayısı (adet) }\end{array}$ & $\begin{array}{c}\text { Meyve } \\
\text { Vermeyen } \\
\text { Yaşta Ağaç } \\
\text { Sayısı (adet) }\end{array}$ & $\begin{array}{c}\text { Toplam } \\
\text { Ağaç } \\
\text { Sayısı } \\
\text { (adet) }\end{array}$ & \\
\hline 2005 & 52814000 & 52523536 & 105337536 & 7857991 & 1585359 & 9443350 & 9.0 \\
\hline 2006 & 54499562 & 55350166 & 109849728 & 7465704 & 1746188 & 9211892 & 8.4 \\
\hline 2007 & 56651476 & 58435665 & 115087141 & 7676462 & 1744755 & 9421217 & 8.2 \\
\hline 2008 & 45269000 & 45003141 & 90272141 & 7502016 & 1774972 & 9276988 & 10.3 \\
\hline 2009 & 46711714 & 47769177 & 94480891 & 7458732 & 1963534 & 9422266 & 10.0 \\
\hline 2010 & 55787611 & 16016269 & 71803880 & 7246675 & 2074842 & 9321517 & 13.0 \\
\hline 2011 & 56987186 & 17691690 & 74678876 & 7236145 & 2011494 & 9247639 & 12.4 \\
\hline 2012 & 60077595 & 19092246 & 79169841 & 7353704 & 2140142 & 9493846 & 12.0 \\
\hline 2013 & 62061115 & 19708438 & 87608346 & 7375020 & 2067969 & 9799561 & 11.2 \\
\hline 2014 & 63996268 & 20834510 & 84830778 & 7395465 & 2056871 & 9452336 & 11.1 \\
\hline 2015 & 67841210 & 21973996 & 89815206 & 7403229 & 2171744 & 9483509 & 10.6 \\
\hline 2016 & 71535277 & 21559251 & 93094528 & 7553044 & 1868862 & 9421906 & 10.1 \\
\hline 2017 & 71801078 & 22628758 & 94429836 & 7567324 & 1816520 & 9383844 & 9.9 \\
\hline 2018 & 77699507 & 18968869 & 96668376 & 7383256 & 1798453 & 9181709 & 9.5 \\
\hline 2019 & 81137900 & 18972971 & 100110871 & 7303315 & 1727764 & 9031079 & 9.0 \\
\hline 2020 & 83530496 & 19119971 & 102650467 & 7010852 & 1722202 & 8636637 & 8.4 \\
\hline
\end{tabular}

Karadeniz Bölgenin yumuşak çekirdekli meyve üretiminde üretim alanında en yüksek paya armut (\% 5.7) ve elma (\% 4.1) sahip olurken üretim miktarı bakımından ise en yüksek paya muşmula sahiptir (\% 38.5). Bu veriler 1şı̆̆ında Karadeniz Bölgesinin ülkemiz yumuşak çekirdekli meyve türlerinin yetiştiriciliğinde özellikle muşmula ve armut üretiminde önemli bir yere sahip olduğu görülmektedir. Türkiye'de muşmula üretiminde alan bakımından 1488 da ile Marmara Bölgesi \% 74.2'lik pay ile ilk sırada olmasına rağmen Karadeniz Bölgesi 1912 (\% 38.2) tonluk üretim miktarıyla ilk sırada yer almaktadır. Muşmula Karadeniz Bölgesi’nde orman altlarında çalı formunda, tarla kenarlarında sınır ağacı şeklinde ve ev bahçelerinde dağınık halde bol miktarda bulunmaktadır. Nitekim bölgede yapılan çalışmalarda muşmulanın doğada bol miktarda bulunduğu belirtilmiştir (Özkan ve ark., 1997; Bostan ve İslam, 2007; Aygün ve Taşcı, 2013; Yılmaz ve Gerçekçioğlu, 2013; Çakır ve Öztürk, 2019; Maral-Gürbüz ve Bostan, 2020). Armut üretiminde ise Karadeniz Bölgesi üretim miktarı bakımından Marmara ve Akdeniz Bölge'lerinden sonra 3. sırada yer almaktadır. Karadeniz Bölgesi'nde ev bahçelerinde ve dağınık halde hem standart hem de pek çok yerel armut çeşidi bulunmaktadır. Çoğunluğu yazlık çeşitlerden oluşan ve özellikle hasat sonrası dayanımı az olan bu yerel armut çeşitleri yerel pazarlarda tüketiciler tarafından beğenilerek satın alınmaktadır. Ayrıca nemli bir ekolojiye sahip olan bölgede özellikle ateş yanıklığı, monilya ve karaleke gibi hastalıklara oldukça dayanıklı bol miktarda yerel elma ve armut çeşidi bulunmaktadır. Bu yerel çeşitlerin çeşit ıslahı çalışmalarında kullanılmak üzere arazi gen bankalarında korunmaya alınması oldukça önem arz 
etmektedir. Yapılan çalışmalarda Karadeniz Bölgesi’nin armut yetiştiriciliği açısından önemli bir potansiyelinin olduğuna vurgu yapılmıştır (Karadeniz ve Şen, 1990; Karadeniz ve Kalkışım, 1996; Demirsoy ve ark., 2007; Bostan, 2009; Bostan ve Acar, 2012; Öztürk ve Demirsoy, 2013; Bostan ve Çelikel-Çubukçu, 2016; Cevahir ve Bostan, 2017; Balta ve ark., 2019).

Çizelge 4. Yumuşak çekirdekli meyve türlerinin 2020 yılındaki Türkiye ve Karadeniz Bölgesi üretim alanları ve üretim miktarlarının karşılaştırılması

\begin{tabular}{|c|c|c|c|c|c|c|}
\hline \multicolumn{3}{|c|}{ Türkiye } & \multicolumn{2}{|c|}{ Karadeniz Bölgesi } & \multirow{2}{*}{$\begin{array}{c}\text { Karadeniz } \\
\text { Bölgesi’nin Türkiye } \\
\text { Yumuşak } \\
\text { Çekirdekli Meyve } \\
\text { Üretim Alanındaki } \\
\text { Payı }(\%)\end{array}$} & \multirow{2}{*}{$\begin{array}{c}\text { Karadeniz } \\
\text { Bölgesi'nin Türkiye } \\
\text { Yumuşak Çekirdekl } \\
\text { Meyve } \\
\text { Üretim Miktarındak } \\
\text { Payı (\%) }\end{array}$} \\
\hline Ürün Adı & $\begin{array}{c}\text { Üretim } \\
\text { Alanı (da) }\end{array}$ & $\begin{array}{c}\text { Üretim } \\
\text { Miktarı (ton) }\end{array}$ & $\begin{array}{c}\text { Üretim } \\
\text { Alanı (da) }\end{array}$ & $\begin{array}{c}\text { Üretim } \\
\text { Miktarı (ton) }\end{array}$ & & \\
\hline Armut & 260707 & 545569 & 14815 & 59931 & 5.7 & 11.0 \\
\hline Ayva & 77376 & 189251 & 2413 & 10230 & 3.1 & 5.4 \\
\hline Elma & 1709032 & 4300486 & 69392 & 149275 & 4.1 & 3.5 \\
\hline Muşmula & 2006 & 4964 & 17 & 1912 & 0.8 & 38.5 \\
\hline Trabzonhurması & 40400 & 60661 & 860 & 3662 & 2.1 & 6.0 \\
\hline Yenidünya & 8094 & 16402 & 0 & 184 & 0.0 & 1.1 \\
\hline TOPLAM & 2097615 & 5117333 & 87497 & 225194 & 4.2 & 4.4 \\
\hline
\end{tabular}

Karadeniz Bölgesi'nde yumuşak çekirdekli meyve türlerinin 2015-2020 yılları arasındaki ağaç sayıları, üretim alanı ve miktarları meyve türlerine göre Çizelge 5'de verilmiştir. Armutta 2015 yılından 2018 yılına kadar artan ağaç sayısı ve meyve üretim alanı 2019-2020 yıllarında azalmış, üretim miktarı ise 2019 yılına kadar artmış 2020 yılında azalmıştır. Ayvada ağaç sayısı 2017 yılına kadar artmış, 2018-2020 yıllarında azalmıştır. Üretim alanı 2015-2020 yılları arasında artarken üretim miktarında genellikle artış ve azalış gösteren bir seyir izlemiştir. Elmada 2015-2020 yılları arasında ağaç sayısında azalma meydana gelmiştir. Özellikle 2019 yılından sonra üretim alanı ve miktarında önemli azalma meydana gelmiştir. 2015-2020 yılları arasında muşmulada ağaç sayısında azalış, üretim alanında artış, üretim miktarında ise 2018 yılına kadara artış görülmüş olup bu yıldan sonra azalmıştır. Trabzonhurmasında 2015-2020 yıllarında ağaç sayısı ve üretim alanında artış, üretim miktarında 2019 yılına kadar artış bu yıldan sonra ise azalış görülmüştür. Yenidünyada ağaç sayısında azalma görülürken, üretim miktarında 2018 yılına kadar artış 2019-2020 yıllarında ise azalma görülmüştür. Türkiye ve Karadeniz Bölgesi yumuşak çekirdekli meyve üretim miktarında önemli bir yeri olan muşmula bölgede diğer bölgelere göre daha düşük az bir alanda (17 da) üretilmesine rağmen üretim miktarı diğer bölgelerden daha yüksektir. Karadeniz Bölgesi'nde muşmulanın kapama bahçeler halinde değil de daha çok ev bahçeleri, tarla kenarları veya ormanlık alanlarda yer alan bitkilerden verimin elde edilmesi üretim miktarındaki fazlalıkta etkili olmaktadır.

\section{Karadeniz Bölgesi Yumuşak Çekirdekli Meyve Türlerinin Dağılımı}

Karadeniz Bölgesi'nde yetiştiriciliği yapılan yumuşak çekirdekli meyve türlerinin 2015 ve 2020 yıllarındaki üretim alanı ve miktarları Çizelge 6'da verilmiştir. Buna göre, yıllar arasındaki üretim değişimine bakıldığında elmada üretim alanı bakımından (\%-16.78) üretim miktarı bakımından ise (\%8.08) azalma görülürken diğer türlerde hem üretim alanı hem de üretim miktarı bakımından artış meydana geldiği görülmektedir. Karadeniz Bölgesi'nde 2015 ve 2020 yılları arasında meyve üretim alanı ve miktarlarına bakıldığında ilk sırayı elma alırken bunu sırasıyla armut, ayva, trabzonhurması, muşmula ve yenidünya izlemiştir (Çizelge 6). Bölgede yıllara göre bu değişime bakıldığında üretim alanı bakımından en fazla artış muşmulada (\% 88.89), üretim miktarı bakımından ise \% 17.20'lik oranla yenidünyada olmuştur. Genel olarak bölgedeki elma, armut, ayva ve trabzonhurması türlerinin diğer meyve türlerine göre üretim alan ve miktarının diğer yumuşak çekirdekli meyve türlerine göre 
yüksek olduğu görülmektedir. Son yıllarda Bölgede bu türlere ait kapama bahçelerin tesis edilmesi sonucunda üretim alanı ve miktarının artışının gerçekleştiği değerlendirilmektedir. Ayrıca bölgede özellikle Doğu ve Batı Karadeniz Bölümü’nde arazi eğiminin fazla, işletme başına düşen arazi büyüklüğünün az ve arazilerin çok parçalı olması yanında yörede üretimin daha çok çay ve findık türleri ile monokültür yetiştiriciliğin yapılmasına bağlı olarak yumuşak çekirdekli meyve türlerinin kapama bahçeler yerine ev bahçelerinde yetiştirilmesi nedeniyle bölgenin meyve üretim miktarı ve alanında artış görülmemektedir.

Çizelge 5. Karadeniz Bölgesi yumuşak çekirdekli meyve türlerinin 2015-2020 yıllarına ait veriler

\begin{tabular}{|c|c|c|c|c|c|c|}
\hline Türler & Yillar & $\begin{array}{l}\text { Meyve Veren } \\
\text { Yaşta Ağaç } \\
\text { Sayısı (adet) }\end{array}$ & $\begin{array}{c}\text { Meyve } \\
\text { Vermeyen Yaşta } \\
\text { Ağaç Sayısı (adet) }\end{array}$ & $\begin{array}{c}\text { Toplam } \\
\text { Ağaç } \\
\text { Sayısı (adet) }\end{array}$ & $\begin{array}{c}\text { Toplu } \\
\text { Meyveliklerin } \\
\text { Alanı (da) } \\
\end{array}$ & $\begin{array}{l}\text { Üretim } \\
\text { Miktarı } \\
\text { (ton) }\end{array}$ \\
\hline \multirow{6}{*}{ Armut } & 2015 & 1989566 & 449284 & 2438850 & 14816 & 56325 \\
\hline & 2016 & 2022362 & 431718 & 2454080 & 16391 & 54258 \\
\hline & 2017 & 2048307 & 415760 & 2464067 & 16396 & 60200 \\
\hline & 2018 & 2078356 & 426737 & 2505093 & 16116 & 60721 \\
\hline & 2019 & 2026630 & 397278 & 2423908 & 15585 & 61087 \\
\hline & 2020 & 1957734 & 393023 & 2350757 & 14815 & 59931 \\
\hline \multirow{6}{*}{ Ayva } & 2015 & 397654 & 89824 & 396014 & 1848 & 9485 \\
\hline & 2016 & 380340 & 85049 & 465389 & 1645 & 6650 \\
\hline & 2017 & 421517 & 88237 & 509754 & 2215 & 10670 \\
\hline & 2018 & 404278 & 89217 & 493495 & 2277 & 10280 \\
\hline & 2019 & 397255 & 89486 & 486741 & 2365 & 10881 \\
\hline & 2020 & 391694 & 86855 & 478549 & 2413 & 10230 \\
\hline \multirow{6}{*}{ Elma } & 2015 & 4786075 & 1568617 & 6354692 & 83380 & 162401 \\
\hline & 2016 & 4914238 & 1286454 & 6200692 & 86402 & 146833 \\
\hline & 2017 & 4861765 & 1245598 & 6107363 & 86059 & 164641 \\
\hline & 2018 & 4663773 & 1215800 & 5879573 & 83349 & 156497 \\
\hline & 2019 & 4642257 & 1174446 & 5816703 & 82852 & 165406 \\
\hline & 2020 & 4423366 & 1175515 & 5598881 & 69392 & 149275 \\
\hline \multirow{6}{*}{ Muşmula } & 2015 & 129529 & 25030 & 154559 & 9 & 1876 \\
\hline & 2016 & 128519 & 24558 & 153077 & 9 & 1913 \\
\hline & 2017 & 128516 & 24233 & 152749 & 8 & 1880 \\
\hline & 2018 & 125833 & 23596 & 149429 & 11 & 1943 \\
\hline & 2019 & 122805 & 22830 & 145635 & 13 & 1922 \\
\hline & 2020 & 121798 & 21281 & 143079 & 17 & 1912 \\
\hline \multirow{6}{*}{ Trabzonhurması } & 2015 & 89360 & 37635 & 126995 & 537 & 3251 \\
\hline & 2016 & 96584 & 39760 & 136344 & 655 & 3648 \\
\hline & 2017 & 96195 & 41327 & 137522 & 668 & 3615 \\
\hline & 2018 & 100264 & 41986 & 142250 & 718 & 4055 \\
\hline & 2019 & 103601 & 42627 & 146228 & 799 & 4147 \\
\hline & 2020 & 105504 & 44451 & 149955 & 860 & 3662 \\
\hline \multirow{6}{*}{ Yenidünya } & 2015 & 11045 & 1354 & 12399 & 0 & 157 \\
\hline & 2016 & 11001 & 1323 & 12324 & 0 & 130 \\
\hline & 2017 & 11024 & 1365 & 12389 & 0 & 139 \\
\hline & 2018 & 10752 & 1117 & 11869 & 0 & 188 \\
\hline & 2019 & 10767 & 1097 & 11864 & 0 & 187 \\
\hline & 2020 & 10756 & 1077 & 11833 & 0 & 184 \\
\hline
\end{tabular}


Türkiye İstatistik Kurumu verilerine göre ayva, muşmula ve trabzonhurması üretim alanının arttığ1, üretim miktarının ise elma dışındaki yumuşak çekirdekli meyve türlerinde arttı̆̆ görülmektedir. Üretim miktarında en fazla artışın olduğu muşmula üretiminin ülkemizde yoğunlukla Samsun ve Sinop illerinde gerçekleştirilmektedir. Muşmula ağaçları daha çok tarla kenarlarında ve bahçelerde dağınık halde ve ormanlık alanlarda doğal olarak yetişmekle birlikte (Bostan ve İslam, 2007; Yılmaz ve Gerçekçioğlu, 2013; Çakır ve Öztürk, 2019) son yıllarda tesis edilen yanında bu üründen ekonomik gelir elde edilmeye başlanmasıyla birlikte kapama bahçelerin verim çağına ulaşmasının ardından üretiminde artış olabileceği değerlendirilmektedir. Bölgede sahil şeridine yakın alanlarda ve çoğunlukla ev bahçelerinde hobi amaçlı olarak yetiştirilen trabzonhurması ve yenidünyada üretim alanı ve miktarı bakımından artış görülmüştür (Tepe, 2013). Ayrıca bölgede yetiştirilen yenidünyaların genellikle tohumdan yetiştirilen bitkiler olması geniş bir genetik çeşitliliğe sahip olmasını sağlamaktadır (Yarılgaç ve ark., 2017; Öztürk ve Öztürk, 2018).

Çizelge 6. 2015-2020 yıllarındaki Karadeniz Bölgesi yumuşak çekirdekli meyve türlerinin üretim alanı ve miktarı arasındaki değişimler

\begin{tabular}{|c|c|c|c|c|c|c|}
\hline \multirow{3}{*}{ Türler } & \multicolumn{4}{|c|}{ Karadeniz Bölgesi } & \multirow{2}{*}{$\begin{array}{r}\text { Karadeniz } \\
\text { Bölgesi'nin } \\
\text { Yumuşak Çekirdekli } \\
\text { Meyve Üretim } \\
\text { Alanındaki Yıllara } \\
\text { Göre Değişimi }(\%)\end{array}$} & \multirow{2}{*}{$\begin{array}{r}\text { Karadeniz Bölgesi’nin } \\
\text { Yumuşak Çekirdekli } \\
\text { Meyve Üretim } \\
\text { Miktarındaki Yıllara Göre } \\
\text { Değişimi (\%) }\end{array}$} \\
\hline & $\begin{array}{l}\text { Üretim } \\
\text { Alanı } \\
\text { (da) }\end{array}$ & $\begin{array}{l}\text { Üretim } \\
\text { Miktarı } \\
\text { (ton) }\end{array}$ & $\begin{array}{l}\text { Üretim } \\
\text { Alanı } \\
\text { (da) }\end{array}$ & $\begin{array}{l}\text { Üretim } \\
\text { Miktarı } \\
\text { (ton) }\end{array}$ & & \\
\hline & 2015 & 2015 & 2020 & 2020 & $2015-2020$ & $2015-2020$ \\
\hline Armut & 14816 & 56325 & 14815 & 59931 & -0.01 & 6.40 \\
\hline Ayva & 1848 & 9485 & 2413 & 10230 & 30.57 & 7.85 \\
\hline Elma & 83380 & 162401 & 69392 & 149275 & -16.78 & -8.08 \\
\hline Muşmula & 9 & 1876 & 17 & 1912 & 88.89 & 1.92 \\
\hline Trabzonhurması & 537 & 3251 & 860 & 3662 & 60.15 & 12.64 \\
\hline Yenidünya & 0 & 157 & 0 & 184 & 0.00 & 17.20 \\
\hline TOPLAM & 100590 & 233495 & 87497 & 225194 & -13.02 & -3.56 \\
\hline
\end{tabular}

Türkiye 2020 y1lı elma üretiminde Starking grubu elmalar üretim alanı 602.966 (\% 35.3) ve üretim miktarı 1675197 (\% 39.0) bakımından en yüksek paya sahipken bunu diğer grup elmalar takip etmiştir. Ülkemiz elma üretiminin alan bakımından \% 4.1 üretim miktarı bakımından \% 3.5'lik kısmını karşılayan Karadeniz Bölgesi'nde diğer grupta yer alan elmalar hem üretim alanı [26 286 (\% 37.9)] hem de üretim miktarı bakımından [54 166 (\% 36.3)] en fazla yetiştirilmişlerdir. Karadeniz Bölgesi'nde bu elmaları üretim alanı bakımından Amasya grubu elmalar [14 535 (\% 20.9)], üretim miktarı bakımından ise Starking grubu elmalar 29389 (\% 19.7)] takip etmiştir. Ayrıca üretim miktarı bakımından Golden grubu elmalar ile Amasya grubu elmalar da bölge üretiminde sırasıyla \% 18.9 ve $\%$ 17.9'luk paya sahiptirler (Çizelge 7).

Çizelge 7. 2020 yılı Türkiye ve Karadeniz Bölgesi'nde üretilen elma çeşitlerinin üretim alanı (da), üretim miktarı (ton) ile payları (\%)

\begin{tabular}{lcccc}
\hline \multirow{2}{*}{ Elmalar } & \multicolumn{2}{c}{ Türkiye } & \multicolumn{2}{c}{ Karadeniz Bölgesi } \\
\cline { 2 - 5 } & $\begin{array}{c}\text { Üretim Alanı (da) ve } \\
\text { Payı }(\%)\end{array}$ & $\begin{array}{c}\text { Üretim Miktarı (ton) } \\
\text { ve Payı }(\%)\end{array}$ & $\begin{array}{c}\text { Üretim Alanı (da) ve Payı } \\
(\%)\end{array}$ & $\begin{array}{c}\text { Üretim Miktarı (ton) ve } \\
\text { Pay1 }(\%)\end{array}$ \\
\hline Golden & $390291(\% 22.8)$ & $1042445(\% 24.2)$ & $10876(\% 15.7)$ & $28173(\% 18.9)$ \\
Starking & $602966(\% 35.3)$ & $1675197(\% 39.0)$ & $12830(\% 18.5)$ & $29389(\% 19.7)$ \\
Amasya & $144744(\% 8.5)$ & $237146(\% 5.5)$ & $14535(\% 20.9)$ & $26715(\% 17.9)$ \\
Granny Smith & $77750(\% 4.5)$ & $175495(\% 4.1)$ & $4865(\% 7.0)$ & $10832(\% 7.3)$ \\
Diğer & $493281(\% 28.9)$ & $1170203(\% 27.2)$ & $26286(\% 37.9)$ & $54166(\% 36.3)$ \\
\hline Toplam & $\mathbf{1 7 0 9 0 3 2}$ & $\mathbf{4 3 0 0 4 8 6}$ & $\mathbf{6 9 3 9 2 ( \% 4 . 1 )}$ & $\mathbf{1 4 9 2 7 5 ( \% 3 . 5 )}$ \\
\hline
\end{tabular}


Karadeniz Bölgesi'nde yumuşak çekirdekli meyve türlerinin 2005-2020 yılları üretim miktarında meydana gelen değişimler Çizelge 8'de verilmiştir. Çizelgeye göre 2019-2020 yılları üretim miktarı değişiminde tüm türlerde azalma meydana gelirken en fazla azalış trabzonhurması (\% - 11.7) ve elmada (\% -9.8) olmuş bunu ayva (\% -6.0) takip etmiştir. Toplam yumuşak çekirdekli meyve üretim miktarında 2019-2020 değişiminde \% -7.6'lık, 2002-2020 değişiminde \% -9.5'lik azalma meydana gelmiştir. Bölgede 2005-2020 üretim miktarında değişimde en fazla azalma elma (\% -12.4), ayva (\% 5.7) ve armut (\% -4.7) olmuştur. $\mathrm{Bu}$ dönemde trabzonhurması, yenidünya ve muşmula üretim miktarında artış meydana gelmiştir (sırasıyla \% 40.8, \% 24.3 ve \% 5.3).

Çizelge 8. 2005-2020 yılları Karadeniz Bölgesi yumuşak çekirdekli meyve türleri üretim miktarları (ton) ve değişimi (\%)

\begin{tabular}{|c|c|c|c|c|c|c|c|}
\hline \multirow{2}{*}{ Ürünler } & \multicolumn{5}{|c|}{ Yillar } & \multirow{2}{*}{$\begin{array}{c}\text { 2019/2020 } \\
\text { Değişim (\%) }\end{array}$} & \multirow{2}{*}{$\begin{array}{c}\text { 2005/2020 } \\
\text { Değişim (\%) }\end{array}$} \\
\hline & 2005 & 2010 & 2015 & 2019 & 2020 & & \\
\hline Armut & 62879 & 59714 & 56325 & 61087 & 59931 & -1.9 & -4.7 \\
\hline Ayva & 10848 & 10289 & 9485 & 10881 & 10230 & -6.0 & -5.7 \\
\hline Elma & 170491 & 162477 & 162401 & 165406 & 149275 & -9.8 & -12.4 \\
\hline Muşmula & 1816 & 2091 & 1876 & 1922 & 1912 & -0.5 & 5.3 \\
\hline Trabzonhurması & 2601 & 2922 & 3251 & 4147 & 3662 & -11.7 & 40.8 \\
\hline Yenidünya & 148 & 145 & 157 & 187 & 184 & -1.6 & 24.3 \\
\hline Toplam & 248783 & 237638 & 233495 & 243630 & 225194 & -7.6 & -9.5 \\
\hline
\end{tabular}

\section{Karadeniz Bölgesi Yumuşak Çekirdekli Meyve Türlerinin İllere Göre Dağılımı}

Batı, Orta ve Doğu Karadeniz olmak üzere 3 bölüme ayrılmakta olup 18 ili içeren Karadeniz Bölgesi'nde yetiştirilen yumuşak çekirdekli meyve (elma, armut, ayva, muşmula, yenidünya ve trabzonhurması) üretim alanı ve miktarı Çizelge 9'da verilmiştir.

Çizelge 9. Karadeniz Bölgesi'nde illere göre yumuşak çekirdekli meyve türlerinin üretim alanı ve üretim miktarının 2015-2020 yılları arasındaki değişimleri

\begin{tabular}{|c|c|c|c|c|c|c|}
\hline İller & $\begin{array}{l}\text { Üretim } \\
\text { Alanı } \\
\text { (da) }\end{array}$ & $\begin{array}{l}\text { Üretim } \\
\text { Miktarı } \\
\text { (ton) }\end{array}$ & $\begin{array}{l}\text { Üretim } \\
\text { Alanı } \\
\text { (da) }\end{array}$ & $\begin{array}{l}\text { Üretim } \\
\text { Miktarı } \\
\text { (ton) }\end{array}$ & $\begin{array}{c}\text { Karadeniz Bölgesi } \\
\text { Yumuşak Çekirdekli } \\
\text { Meyve Üretim } \\
\text { Alanındaki Yıllara Göre } \\
\text { Değişim }(\%)\end{array}$ & $\begin{array}{c}\text { Karadeniz Bölgesi } \\
\text { Yumuşak Çekirdekli } \\
\text { Meyve Üretim } \\
\text { Miktarındaki Yıllara Göre } \\
\text { Değişim }(\%)\end{array}$ \\
\hline & 2015 & 2015 & 2020 & 2020 & $2015-2020$ & $2015-2020$ \\
\hline Amasya & 15753 & 40398 & 15764 & 46004 & 0.1 & 13.9 \\
\hline Artvin & 2725 & 6872 & 2877 & 6058 & 5.6 & -11.8 \\
\hline Bartın & 5131 & 10730 & 5363 & 10695 & 4.5 & -0.3 \\
\hline Bayburt & 530 & 795 & 855 & 763 & 61.3 & -4.0 \\
\hline Bolu & 20434 & 31466 & 6046 & 15527 & -70.4 & -50.7 \\
\hline Çorum & 9714 & 12065 & 414 & 12189 & -13.4 & 1.0 \\
\hline Düzce & 518 & 6221 & 505 & 935 & -2.5 & -85.0 \\
\hline Giresun & 1383 & 9643 & 698 & 9660 & -49.5 & 0.2 \\
\hline Gümüşhane & 4503 & 6068 & 4328 & 6730 & -3.9 & 10.9 \\
\hline Karabük & 1174 & 2899 & 1052 & 3465 & -10.4 & 19.5 \\
\hline Kastamonu & 8192 & 16779 & 14549 & 21509 & 77.6 & 28.2 \\
\hline Ordu & 154 & 11277 & 225 & 12968 & 46.1 & 15.0 \\
\hline Rize & 292 & 2165 & 249 & 2412 & -14.7 & 11.4 \\
\hline Samsun & 6768 & 29522 & 4087 & 27874 & -39.6 & -5.6 \\
\hline Sinop & 4345 & 9543 & 4320 & 10381 & -0.6 & 8.8 \\
\hline Tokat & 14969 & 21297 & 12228 & 20450 & -18.3 & -4.0 \\
\hline Trabzon & 499 & 9427 & 517 & 11714 & 3.6 & 24.3 \\
\hline Zonguldak & 3506 & 6328 & 5420 & 5860 & 54.6 & -7.4 \\
\hline
\end{tabular}


Çizelge 10. Karadeniz Bölgesi'nde illere göre yetiştiriciliği yapılan yumuşak çekirdekli meyve türlerinin 2020 yılı üretim alanı ve miktarı ile bunların bölgedeki payları

\begin{tabular}{|c|c|c|c|c|c|}
\hline İller & Türler & $\begin{array}{l}\text { Meyve Üretim Alanı } \\
\text { (da) }\end{array}$ & $\begin{array}{l}\text { Meyve Üretim Miktar } \\
\text { (ton) }\end{array}$ & $\begin{array}{c}\text { Meyve Türünün } \\
\text { Karadeniz Bölgesi } \\
\text { Üretim Alanındaki } \\
\text { Payı (\%) }\end{array}$ & $\begin{array}{c}\text { Meyve Türünün } \\
\text { Karadeniz Bölgesi } \\
\text { Üretim Miktarındaki } \\
\text { Payı (\%) }\end{array}$ \\
\hline \multirow[t]{4}{*}{ Amasya } & Armut & 1411 & 7631 & 1.61 & 3.39 \\
\hline & Ayva & 394 & 3693 & 0.45 & 1.64 \\
\hline & Elma & 13813 & 34131 & 15.79 & 15.16 \\
\hline & Trabzonhurması & 146 & 549 & 0.17 & 0.24 \\
\hline \multirow[t]{6}{*}{ Artvin } & Armut & 517 & 1790 & 0.59 & 0.79 \\
\hline & Ayva & 302 & 378 & 0.35 & 0.17 \\
\hline & Elma & 1940 & 3104 & 2.22 & 1.38 \\
\hline & Muşmula & 0 & 27 & 0.00 & 0.01 \\
\hline & Trabzonhurması & 118 & 750 & 0.13 & 0.33 \\
\hline & Yenidünya & 0 & 9 & 0.00 & 0.00 \\
\hline \multirow{5}{*}{ Bartın } & Armut & 1986 & 5222 & 2.27 & 2.32 \\
\hline & Ayva & 42 & 356 & 0.05 & 0.16 \\
\hline & Elma & 3335 & 4999 & 3.81 & 2.22 \\
\hline & Muşmula & 0 & 117 & 0.00 & 0.05 \\
\hline & Trabzonhurması & 0 & 1 & 0.00 & 0.00 \\
\hline \multirow[t]{2}{*}{ Bayburt } & Armut & 145 & 126 & 0.17 & 0.06 \\
\hline & Elma & 710 & 637 & 0.81 & 0.28 \\
\hline \multirow[t]{4}{*}{ Bolu } & Armut & 881 & 2688 & 1.01 & 1.19 \\
\hline & Ayva & 139 & 260 & 0.16 & 0.12 \\
\hline & Elma & 5024 & 12561 & 5.74 & 5.58 \\
\hline & Muşmula & 2 & 18 & 0.00 & 0.01 \\
\hline \multirow[t]{5}{*}{ Çorum } & Armut & 586 & 3103 & 0.67 & 1.38 \\
\hline & Ayva & 648 & 1349 & 0.74 & 0.60 \\
\hline & Elma & 7178 & 7585 & 8.20 & 3.37 \\
\hline & Muşmula & 0 & 143 & 0.00 & 0.06 \\
\hline & Trabzonhurması & 2 & 9 & 0.00 & 0.00 \\
\hline \multirow[t]{6}{*}{ Düzce } & Armut & 200 & 158 & 0.23 & 0.07 \\
\hline & Ayva & 3 & 68 & 0.00 & 0.03 \\
\hline & Elma & 265 & 330 & 0.30 & 0.15 \\
\hline & Muşmula & 0 & 156 & 0.00 & 0.07 \\
\hline & Trabzonhurması & 37 & 195 & 0.04 & 0.09 \\
\hline & Yenidünya & 0 & 28 & 0.00 & 0.01 \\
\hline \multirow[t]{5}{*}{ Giresun } & Armut & 57 & 3241 & 0.07 & 1.44 \\
\hline & Ayva & 0 & 210 & 0.00 & 0.09 \\
\hline & Elma & 637 & 6129 & 0.73 & 2.72 \\
\hline & Muşmula & 0 & 38 & 0.00 & 0.02 \\
\hline & Trabzonhurması & 4 & 42 & 0.00 & 0.02 \\
\hline \multirow[t]{3}{*}{ Gümüşhane } & Armut & 675 & 1905 & 0.77 & 0.85 \\
\hline & Ayva & 235 & 84 & 0.27 & 0.04 \\
\hline & Elma & 3418 & 4741 & 3.91 & 2.11 \\
\hline \multirow[t]{5}{*}{ Karabük } & Armut & 58 & 664 & 0.07 & 0.29 \\
\hline & Ayva & 38 & 407 & 0.04 & 0.18 \\
\hline & Elma & 933 & 2314 & 1.07 & 1.03 \\
\hline & Muşmula & 0 & 74 & 0.00 & 0.03 \\
\hline & Trabzonhurması & 23 & 6 & 0.03 & 0.00 \\
\hline
\end{tabular}

Bölgede 2020 yılında yumuşak çekirdekli meyve üretim alanının en fazla olduğu iller Amasya, Kastamonu ve Tokat iken bu illeri Çorum ve Bolu izlemiştir. Meyve üretim miktarı 2020 yılında en fazla olduğu iller Amasya, Samsun ve Kastamonu iken bu illeri Bolu, Ordu ve Çorum takip etmiştir. 2015 ve 2020 yılları arasında bölgedeki meyve üretim alanı bakımından en fazla artış Kastamonu (\% 77.6), Bayburt (\% 61.3) ve Zonguldak (\% 54.6), azalış ise Bolu (\% -70.4), Giresun (\% -49.5) ve Samsun (\% -39.6) illerinde olmuştur. 2015-2020 yılları arasında bölgede yumuşak çekirdekli meyve üretim miktarı bakımından en fazla artış Kastamonu (\% 28.2), Trabzon (\% 24.3) ve Karabük (\% 19.5), azalış ise Düzce (\% -85.0), Bolu (\% -50.7) ve Artvin (\% -11.8) illerinde olmuştur (Çizelge 9). Azalış görülen bu illerde meyve üretim alanı ve miktarının düşük olmasının sebepleri arasında eğimin fazla 
olması ve yörede daha çok fındık, ceviz ve çayın yetiştirilmesi gösterilebilir. Bayburt ilinin soğuk iklime sahip olması ve bu ekolojik koşullara elma ve armut dışında uygun yumuşak çekirdekli meyve tür ve çeşitlerinin yetiştirilmemesi üretim alanı ve miktarındaki azalışa neden olmaktadır. Bolu, Samsun, Tokat, Giresun ve Çorum illerinde fazla miktarda yetiştirilen elma, armut ve ayvanın hastalık ve zararlılar dolayısıyla yoğun ilaçlı mücadeleye ihtiyaç duyması ve üreticinin yeterince gelir elde edememesi üreticilerin bu ürünler yerine fındık, ceviz, kivi, kiraz vb. ürünlerin yetiştiriciliğine yönelmesine neden olmaktadır.

Çizelge 10. Karadeniz Bölgesi'nde illere göre yetiştiriciliği yapılan yumuşak çekirdekli meyve türlerinin 2020 yılı üretim alanı ve miktarı ile bunların bölgedeki payları (Devam)

\begin{tabular}{|c|c|c|c|c|c|}
\hline İller & Türler & $\begin{array}{l}\text { Meyve Üretim Alanı } \\
\text { (da) }\end{array}$ & $\begin{array}{l}\text { Meyve Üretim Miktar } \\
\text { (ton) }\end{array}$ & $\begin{array}{c}\text { Meyve Türünün } \\
\text { Karadeniz Bölgesi } \\
\text { Üretim Alanındaki } \\
\text { Payı (\%) }\end{array}$ & $\begin{array}{c}\text { Meyve Türünün } \\
\text { Karadeniz Bölgesi } \\
\text { Üretim Miktarındak } \\
\text { Pay1 (\%) }\end{array}$ \\
\hline \multirow[t]{5}{*}{ Kastamonu } & Armut & 1448 & 4732 & 1.65 & 2.10 \\
\hline & Ayva & 47 & 439 & 0.05 & 0.19 \\
\hline & Elma & 13042 & 16247 & 14.91 & 7.21 \\
\hline & Muşmula & 5 & 44 & 0.01 & 0.02 \\
\hline & Trabzonhurmas1 & 7 & 47 & 0.01 & 0.02 \\
\hline \multirow[t]{6}{*}{ Ordu } & Armut & 0 & 4117 & 0.00 & 1.83 \\
\hline & Ayva & 0 & 255 & 0.00 & 0.11 \\
\hline & Elma & 150 & 7741 & 0.17 & 3.44 \\
\hline & Muşmula & 0 & 78 & 0.00 & 0.03 \\
\hline & Trabzonhurmas1 & 75 & 776 & 0.09 & 0.34 \\
\hline & Yenidünya & 0 & 1 & 0.00 & 0.00 \\
\hline \multirow{6}{*}{ Rize } & Armut & 0 & 1045 & 0.00 & 0.46 \\
\hline & Ayva & 0 & 21 & 0.00 & 0.01 \\
\hline & Elma & 125 & 997 & 0.14 & 0.44 \\
\hline & Muşmula & 0 & 8 & 0.00 & 0.00 \\
\hline & Trabzonhurmas1 & 124 & 285 & 0.14 & 0.13 \\
\hline & Yenidünya & 0 & 56 & 0.00 & 0.02 \\
\hline \multirow[t]{5}{*}{ Samsun } & Armut & 951 & 7604 & 1.09 & 3.38 \\
\hline & Ayva & 72 & 1232 & 0.08 & 0.55 \\
\hline & Elma & 2966 & 17881 & 3.39 & 7.94 \\
\hline & Muşmula & 10 & 463 & 0.01 & 0.21 \\
\hline & Trabzonhurmas1 & 88 & 694 & 0.10 & 0.31 \\
\hline \multirow[t]{5}{*}{ Sinop } & Armut & 1115 & 3246 & 1.27 & 1.44 \\
\hline & Ayva & 17 & 410 & 0.02 & 0.18 \\
\hline & Elma & 3168 & 6354 & 3.62 & 2.82 \\
\hline & Muşmula & 0 & 345 & 0.00 & 0.15 \\
\hline & Trabzonhurmas1 & 20 & 26 & 0.02 & 0.01 \\
\hline \multirow[t]{5}{*}{ Tokat } & Armut & 2553 & 6398 & 2.92 & 2.84 \\
\hline & Ayva & 149 & 441 & 0.17 & 0.20 \\
\hline & Elma & 9526 & 13482 & 10.89 & 5.99 \\
\hline & Muşmula & 0 & 75 & 0.00 & 0.03 \\
\hline & Trabzonhurmasi & 0 & 54 & 0.00 & 0.02 \\
\hline \multirow[t]{6}{*}{ Trabzon } & Armut & 75 & 3880 & 0.09 & 1.72 \\
\hline & Ayva & 6 & 348 & 0.01 & 0.15 \\
\hline & Elma & 220 & 6919 & 0.25 & 3.07 \\
\hline & Mușmula & 0 & 249 & 0.00 & 0.11 \\
\hline & Trabzonhurmas 1 & 216 & 228 & 0.25 & 0.10 \\
\hline & Yenidünya & 0 & 90 & 0.00 & 0.04 \\
\hline \multirow[t]{4}{*}{ Zonguldak } & Armut & 2157 & 2381 & 2.47 & 1.06 \\
\hline & Ayva & 321 & 279 & 0.37 & 0.12 \\
\hline & Elma & 2942 & 3123 & 3.36 & 1.39 \\
\hline & Mușmula & 0 & 77 & 0.00 & 0.03 \\
\hline
\end{tabular}

Karadeniz Bölgesi illerinin 2020 y1lı yumuşak çekirdekli meyve türlerinin üretim alanı ve miktarı Çizelge 10'da verilmiştir. Buna göre, elma üretiminde en büyük paya sahip olan iller Amasya, Samsun, Kastamonu ve Tokat'tır [sirasiyla, 34131 ton (\% 22.9), 17881 ton (\% 12.0), 16247 ton (\% 10.9) ve 13482 ton (\% 9.0)]. Bu illerde özellikle Amasya ve Tokat yöresinde meyvecilik için hem 
uygun ekolojik koşulların olması hem de ürünlerin farklı değerlendirme şekline yönelik tarım sanayisinin gelişmesi (örneğin meyve suyu), meyve üretim alanı ve miktarını arttırmıştır. Armut yetiştiriciliğinde en fazla üretim payına sahip olan iller Amasya, Samsun, Tokat ve Bartın [sırasıyla 7 631 ton (\% 12.7), 7604 ton (\% 12.7), 6398 ton (\% 10.7) ve 5222 ton (\% 8.7)], ayvada ise Amasya (3 693 ton, \% 36.1) olup bunu sirasıyla Çorum (1 349 ton, \% 13.2) ve Samsun (1 232 ton, \% 12.0) illeri takip etmektedir. Trabzonhurmasında Ordu, Artvin, Samsun ve Amasya; yenidünyada Trabzon, Rize ve Düzce, muşmulada Samsun, Sinop, Trabzon, Düzce ve Çorum illeri en fazla üretime sahip illerdir.

\section{SONUÇ}

Karadeniz Bölgesi'nin yumuşak çekirdekli meyve türlerinin üretim alanı ve miktarının yıllar itibariyle değişiminin incelendiği bu çalışmada tüm istatistiki veriler karşılaştırmalı olarak ortaya konulmuştur. 2005-2020 yılları arasındaki yumuşak çekirdekli meyve türlerinin üretim alanı ve miktarı bakımından hem Türkiye hem de Karadeniz Bölgesi’nde artış olduğu görülmüştür. Karadeniz Bölgesi'nde yumuşak çekirdekli meyve türlerinden elma en fazla üretimi yapılan türdür, bunu sırasıyla armut ve ayva takip etmiştir. Bölgede yumuşak çekirdekli meyve üretimi bakımından ilk sırada Amasya ili olup bunu Samsun, Kastamonu, Tokat ve Bolu illeri izlemektedir. Bu illerde özellikle elma, armut ve ayva üretimi ön plana çıkmaktadır. Orta ve Doğu Karadeniz Bölgesi’nde ise elma, armut ve ayva ağaçları ise kapama bahçe şeklinde değil fındık ve çay bahçelerinin kenarlarında ya da içlerinde yetiştirilmektedir.

Bölgede yumuşak çekirdekli meyve türlerinde genellikle yerel çeşitlerin kullanılması ve bunların çoğunlukla yazlık çeşitlerden oluşması, verim ve kalitelerinin düşük olması yanında bakım şartlarının da iyi olmaması bölgede verimin yıllara göre dalgalanmalar göstermesine neden olmaktadır. Özellikle yetiştiriciliğe uygun alanlarda bölge ekolojik koşullarına uygun, verim ve kalitesi yüksek standart ve yerel çeşitlerin uygun anaçlar kullanılarak yetiştirilmesi meyve verim ve kalitesinin artmasına yardımcı olacaktır.

Bölgede son yıllarda üzerinde çok fazla durulan ve üreticilerin de yoğun ilgi gösterdiği bodur meyve yetiştiriciliğinin uygun alanlarda yaygınlaştırılması bölge meyveciliği için önemli bir avantaj sağlayacaktır. Yumuşak çekirdekli meyve yetiştiriciliğinde ön sıralarda yer alan başta Amasya, Samsun, Kastamonu, Tokat ve Bolu illeri olmak üzere modern meyvecilik tekniklerinin de kullanıldı̆̆ bahçelerin tesis edilmesi teşvik edilmelidir. Yetiştiriciliğin teşvik edilmesinin yanı sıra işleme, muhafaza ve pazarlama ağı da güçlendirilmelidir.

Sonuç olarak Karadeniz Bölgesi yumuşak çekirdekli meyve üretiminde özellikle elma, armut, ayva, trabzonhurması ve muşmula yetiştiriciliğinde önemli bir yere sahip iken bölgede diğer yumuşak çekirdekli meyve türlerinden olan yenidünya, alıç, ahlat, üvez de yetiştirilebilmektedir. Bölgede elma, armut, ayva, trabzonhurması, yenidünya ve muşmula gibi genetik çeşitliliği fazla olan türlerde meyve verim ve kalitesi bakımından üstün olan genotiplerin belirlenmesi ve yeni çeşitlerin geliştirilmesine yönelik ıslah çalışmalarına hız verilmesi bölge ekonomisine katkı sağlayacaktır.

\section{Çıkar Çatışması}

Makale yazarları arasında herhangi bir çıkar çatışması olmadığg beyan olunur.

\section{Yazar Katkısı}

Yazarlar makaleye eşit oranda katkı sağlamışlardır. 


\section{KAYNAKLAR}

Ağaoğlu YS, Çelik H, Çelik M, Fidan Y, Gülşen Y, Günay A, Halloran N, Köksal Aİ, Yanmaz R, 2015. Genel Bahçe Bitkileri (Güncelleştirilmiş 7. Baskı). Ankara Üniversitesi Ziraat Fakültesi Ders Kitabı, Yayın No: 1630, 369 s, Ankara-Türkiye.

Anonim 2021. Karadeniz Bölgesi. http://www.cografya.gen.tr/egitim/bolgeler/karadeniz.htm. (Erişim tarihi: 10.02.2021)

Aygün A, Taşçı AR, 2013. Some Fruit Characteristics of Medlar (Mespilus germanica L.) Genotypes Grown in Ordu, Turkey. Scientific Papers. Series B, Horticulture. Vol. LVII: 149-151.

Aygün A, Ülgen SA, 2009. Rize'de yetiştirilen Demir Elma (Malus communis L.) çeşidinin bazı meyve özelliklerinin belirlenmesi. Tarım Bilimleri Araştırma Dergisi, 2: 201-205.

Bak T, Şenyurt M, Karadeniz T, 2016. Ordu Ulubey ilçesinde yetişen ayva (Cydonia oblonga) genotiplerinin meyve özelliklerinin belirlenmesi. Bahçe (Özel Say1), 45(1): 489-492.

Balta MF, Üç L, Karakaya O, 2019. Şebinkarahisar (Giresun) İlçesinde Seçilen Alişar Armut Klonlarının Bazı Meyve Özellikleri. Uluslararası Tarım ve Yaban Hayatı Bilimleri Dergisi, 5(1): 31 - 37

Bostan SZ, 2009. Pomological Traits of Local Apple and Pear Cultivars and Types Grown in Trabzon Province (Eastern Black Sea Region of Turkey). Acta Horticulture, 825:293-298.

Bostan SZ, Acar Ş, 2012. Ünye'de (Ordu) yetiştirilen mahalli armut çeşitlerinin pomolojik özellikleri. Akademik Ziraat Dergisi, 1(2): 97-106.

Bostan SZ, Çelikel-Çubukçu G, 2016. Çaykara İlçesinde Yetiştirilen Güzlük ve Kışlık Mahalli Armut Çeşitlerinin Pomolojik Özellikleri. Bahçe (Özel Say1), 45(1): 59-68.

Bostan SZ, İslam A, 2007. Doğu Karadeniz Bölgesi muşmulalarının (Mespilus germanica L.) seleksiyon yoluyla 1slahı üzerine bir araştırma. Türkiye V. Ulusal Bahçe Bitkileri Kongresi, Bildiriler Kitab1, Erzurum, 4-7 Eylül, 1:494-501.

Cevahir G, Bostan SZ, 2017. Of (Trabzon) ilçesi yerel armutlan: Erkenci ve orta mevsim çeşitleri. Meyve Bilimi, 4(2): 19-25.

Çakır E, Öztürk A, 2019. Samsun İli Tekkeköy İlçesinde Yetişen Ümitvar Muşmula Genotiplerinin Belirlenmesi. Uluslararası Tarım ve Yaban Hayatı Bilimleri Dergisi, 5(2): 240 - 249

Çiftçi DT, Sağır N, Bağcı MD, Aygün A, 2011. Doğu Karadeniz Sahil Bölgesinde Yetiştirilen Yerel Armut (Pyrus spp.) Çeşitlerinin Bazı Özelliklerinin Belirlenmesi. Türkiye VI. Ulusal Bahçe Bitkileri Kongresi, Şanlıurfa, 04-08 Ekim, 1:798-806.

Davis PH, 1972. Flora of Turkey and The East Aegean Islands. Edinburgh University Press, Vol. 4., Edinburgh.

Demirsoy L, Öztürk A, Serdar Ü, Duman E, 2007. Saklı Cennet Camili'de Yetiştirilen Yerel Armut Çeşitleri. Türkiye V. Ulusal Bahçe Bitkileri Kongresi, Erzurum, 04-07 Eylül, 1: 396-400.

Dost SE, Dumanoğlu H, 2018. Doğu Karadeniz Bölgesi Sahil Kuşağı Yerel Elma Çeşit Koleksiyonu’nda (Ankara) Ümitvar Sofralık Genotiplerin Belirlenmesi. Gaziosmanpaşa Üniversitesi Ziraat Fakültesi Dergisi, 35 (Ek Say1):38-46.

Dumanoğlu H, Aygün A, Erdoğan V, Serdar Ü, Kalkışım Ö, Baştaş K, Pakyürek MA, Maden S, 2011. Doğu Karadeniz Bölgesi Sahil Kuşağındaki Bazı Yerel Elma Çeşitlerinin Meyve Özellikleri Bakımından Değerlendirilmesi. Türkiye VI. Ulusal Bahçe Bitkileri Kongresi, Şanlıurfa, 04-08 Ekim, 1: 173-180.

Dumanoğlu H, Erdoğan V, Aygün A, Javadisaber J, 2009. Ankara İlinde "Granny Smith” Elma Çeşidinde Ekstrem Yaz İklimi Koşullarının Meyve Kalite Özellikleri Üzerine Etkisi. Tarım Bilimleri Araştırma Dergisi, 2 (2): 193-199.

FAOSTAT 2021. Statistical Database of the Food and Agricultural Organization. http://www.fao.org/faostat/en/\#data/QC (Erişim tarihi: 25.01.2021)

Karadeniz T, Kalkışım Ö, 1996. Görele ve Çevresinde Yetiştirilen Mahalli Yazlık Armut Çeşitleri Üzerinde Pomolojik Çalışmalar. Yüzüncü Y1l Üniversitesi Ziraat Fakültesi Dergisi, 6(1): 81-86. 
Karadeniz T, Şen SM, 1990. Tirebolu ve Çevresinde Yetiştirilen Mahalli Armut Çeşitlerinin Pomolojik ve Morfolojik Özellikleri Üzerine Araştırmalar. Yüzüncü Yıl Üniversitesi Ziraat Fakültesi Dergisi, 1/1: 152165.

Karakaya O, Balta MF, Kaya T, Uzun S, 2016. Yağlidere (Giresun) elmaları: fenolojik ve pomolojik özellikler. Bahçe (Özel Sayı) 1:925-929.

Maral Gürbüz E, Bostan SZ 2020. Çarşamba İlçesi (Samsun) Ümitvar Muşmula Genotiplerinin Fiziksel ve Kimyasal Karakterizasyonu. Kahramanmaraş Sütçü İmam Üniversitesi Tarım ve Doğa Dergisi, 23 (4): 816-823.

Özkan Y, Gerçekcioğlu R, Polat M, 1997. Tokat merkez ilçede yetiştirilen muşmula (Mespilu germanica L.) tiplerinin meyve özelliklerinin belirlenmesi üzerine bir araştırma. Yumuşak Çekirdekli Meyveler Sempozyumu. Yalova, 2-5 Eylül, 123-129.

Öztürk A, Demirsoy L, 2013. Promising pear genotypes from North Anatolia, Turkey: Preliminary Observations. Journal of the American Pomological Society, 67 (4): 217-227.

Öztürk A, Karabulut B, 2017. Karadeniz Bölgesi’nde Organik Bitkisel Üretim. Türk Tarım - Gıda Bilim ve Teknoloji Dergisi, 5(13): 1705-1713.

Öztürk A, Öztürk B, 2018. Determination of Fruit Quality Properties of Loquat Genotypes Grown in Ordu Province of Turkey. International Journal of Scientific and Technological Research, 4(10): 262-268.

Öztürk A, Serttaş S, 2018. Karadeniz Bölgesi Meyveciliğinin Mevcut Durumu ve Potansiyeli. Iğdır Üniversitesi Fen Bilimleri Enstitüsü Dergisi, 8(4): 11-20.

Saraçoğlu, O., Kalkışım, Ö., Çekiç, Ç., Özgen, M. 2011. 'Yomra’ve ‘Granny Smith’Elma Çeşitlerinin Modifiye Atmosfer Koşullarında Muhafaza Edilebilirliğinin Karşılaştırılması. Gümüşhane Üniversitesi Fen Bilimleri Enstitüsü Dergisi, 1:40-46.

Serdar Ü, Ersoy B, Öztürk A, Demirsoy H, 2007. Saklı cennet Camili'de yetiştirilen yerel elma çeşitleri. Türkiye V. Ulusal Bahçe Bitkileri Kongresi, Erzurum, 04-07 Eylül, 1: 575-579.

Şenyurt M, Bak T, Karadeniz T, 2016. Ordu ili Ulubey ilçesinde yetişen bazı Trabzon Hurması (Diospyros kaki) tiplerinin pomolojik özellikleri. Bahçe (Özel Say1), 45(1): 574-578.

Tepe S, 2013. Yenidünya yetiştiriciliği ve geleceği. Tarım Türk, 42(8): 64-66.

TÜIK, 2021. Türkiye İstatistik Kurumu. https://biruni.tuik.gov.tr/bitkiselapp/bitkisel.zul. (Erişim tarihi: 15.03.2021)

Yarılgaç T, Balcı MA, Uzun S, Balta MF, 2017. Trabzon ili merkez ilçeden selekte edilen yenidünya genotiplerinin fiziksel ve bazı kimyasal özellikleri. Iğdır Üniversitesi Fen Bilimleri Enstitüsü Dergisi, 7(1): 11-15.

Yarılgaç T, Karadeniz T, Gürel HB, 2009. Ordu Merkez ilçede yetiştirilen yöresel elma (Malus communis L.) çeşitlerinin fenolojik ve pomolojik özelliklerinin belirlenmesi. Tarım Bilimleri Araştırma Dergisi, 2: 37 41.

Yılmaz A, Gerçekcioğlu R, 2013. Tokat ekolojisi muşmula (Mespilus germanica L.) popülasyonu ve dağılımı üzerine bir araştırma. Tarım Bilimleri Araştırma Dergisi, 6 (2): 1-4. 